\title{
Methylmalonic Aciduria, cblA Type
}

National Cancer Institute

\section{Source}

National Cancer Institute. Methylmalonic Aciduria, cblA Type. NCI Thesaurus. Code C142171.

An autosomal recessive form of methylmalonic aciduria, caused by mutation(s) in the MMAA gene, encoding MMAA protein. 